\title{
Bacterium-like particles as multi-epitope delivery platform for Plasmodium berghei circumsporozoite protein induce complete protection against malaria in mice
}

Krystelle Nganou-Makamdop ${ }^{1}$, Maarten L van Roosmalen², Sandrine AL Audouy ${ }^{3}$, Geert-Jan van Gemert ${ }^{1}$, Kees Leenhouts ${ }^{2}$, Cornelus C Hermsen ${ }^{1 *}$ and Robert W Sauerwein ${ }^{1}$

\begin{abstract}
Background: Virus-like particles have been regularly used as an antigen delivery system for a number of Plasmodium peptides or proteins. The present study reports the immunogenicity and protective efficacy of bacterium-like particles (BLPS) generated from Lactococcus lactis and loaded with Plasmodium berghei circumsporozoite protein (PbCSP) peptides.
\end{abstract}

Methods: A panel of BLP-PbCSP formulations differing in composition and quantity of B-cell, CD4+ and CD8+ Tcell epitopes of PbCSP were tested in BALB/C mice.

Results: BLP-PbCSP1 induced specific humoral responses but no IFN- $\gamma$ ELISPOT response, protecting 30-40\% of the immunized mice. BLP-PbCSP2, with reduced length of the non-immunogenic part of the T-cell-epitopes construct, increased induction of IFN- $\gamma$ responses as well as protection up to 60-70\%. Compared to controls, lower parasitaemia was observed in unprotected mice immunized with BLP-PbCSP1 or 2, suggestive for partial immunity. Finally, further increase of the number of B-cell epitopes and codon optimization (BLP-PbCSP4) induced the highest anti-CSP antibody levels and number of IFN- $\gamma$ spots, resulting in sterile immunity in $100 \%$ of the immunized mice.

Conclusion: Presentation of Plasmodium-derived antigens using BLPS as a delivery system induced complete protection in a murine malaria model. Eventually, BLPs have the potential to be used as a novel versatile delivery platform in malaria vaccine development.

Keywords: BLP, CSP, Delivery platform, Immunization, Malaria, Plasmodium berghei

\section{Background}

By 2009, nearly a quarter of a billion people worldwide suffered from a malaria infection that resulted in approximately 800,000 deaths each year, mainly of children in sub-Saharan Africa [1]. Long-term solutions to stop deaths caused by malaria include the development of a prophylactic vaccine. Pre-erythrocytic stages of the parasite have been the principle target for vaccine development [2]. Effective delivery systems are required to

\footnotetext{
* Correspondence: r.hermsen@ncmls.ru.nl

'Department of Medical Microbiology, Radboud University Nijmegen Medical Centre, P. O. Box 9101, 6500 HB Nijmegen, The Netherlands Full list of author information is available at the end of the article
}

optimize immune responses and protection by sub-unit based vaccines [3]. As such, virus-like particles (VLPs) have emerged as promising candidates able to induce cell-mediated immunity [4]. Due to its abundant presence on the sporozoite's surface [5], the circumsporozoite protein (CSP) has been the prime target for preerythrocytic protein-based malaria vaccine development [6-9]. In the Plasmodium berghei murine model, CSP immunizations with virally vectored delivery systems have been to shown to induce potent CD8 $+\mathrm{T}$-cell responses [10-13]. However, strong CD8+ T-cell responses associated with high protection levels is only achieved by using different viral vectors in a prime-

\section{Biomed Central}


boost strategy. Pre-existing immunity, by natural exposure or VLP prime immunization, might reduce the efficacy of a subsequent boost immunization with the same VLP [4]. Moreover, concerns for safety were recently raised from a clinical trial of an Ad5-vectored HIV vaccine, in which excess HIV infections were observed in vera with pre-existing Ad5 antibodies [14]. Both the necessity of prime-boost immunizat!ion withdifferent carriers and the uncertainties about safety profiles could represent hurdles for development of a malaria VLP vaccine; emphasizing the need for alternative delivery platforms.

Previous studies have described a multifunctional carrier system based on Lactococcus lactis [15,16], for which prime immunization has been shown not to reduce the efficacy of booster immunizations [17]. By simple hot acid pre-treatment, these bacteria are converted in a non-living particle delivery system with selfadjuvanting properties, called bacterium-like particles (BLPs). BLPs can be simply mixed with antigens to stimulate immune responses. The best stimulation is obtained when the antigen is attached to the particle [17]. Strong, but non-covalent attachment of antigens to the surface of BLPs is mediated by using a lactococcal peptidoglycan binding domain called Protan [18]. Hybrid antigen-Protan fusion proteins can be secreted by a recombinant production system. When the cell-free culture medium is mixed with BLPs, Protan-fusion proteins bind with high affinity. Applications of BLP-based delivery have been successful for influenza [19,20], Yersinia pestis [21] and Streptococcus pneumoniae [22]. In a previous study, the ability of Lactococcus lactis BLPs to elicit systemic antibodies against the Plasmodium falciparum merozoite surface antigen 2 was evaluated [23]. In the present study, immune responses and protective efficacy were studied in a murine model following parenteral immunizations with BLPs carrying Plasmodium berghei circumsporozoite protein (PbCSP) peptides.

\section{Methods}

\section{Bacterial strains and growth conditions}

Strains and plasmids used in this study are listed in Table 1. Lactococcus lactis strains were grown at $30^{\circ} \mathrm{C}$ in M17 broth (Oxoid) containing $0.5 \%$ glucose $(\mathrm{w} / \mathrm{v})$ (GM17) and, when necessary, supplemented with chloramphenicol $(5 \mu \mathrm{g} / \mathrm{ml})$ for plasmid selection. $\mathrm{P}_{\text {nisA }}$-driven gene expression was induced with the culture supernatant of the nisin-producing L. lactis strain NZ9700 as described previously [24]. Escherichia coli strains were grown in Luria-Bertani (LB) liquid medium or on agar plates at $37^{\circ} \mathrm{C}$ both supplemented with $100 \mu \mathrm{g} / \mathrm{ml}$ ampicillin. Enzymes and buffers were purchased from New England Biolabs (USA) or Roche (The Netherlands). Electro-transformation of L. lactis was carried out as described by Holo and Nes [25] using a Bio-Rad Gene Pulser.

\section{Plasmid construction and production of antigens}

PbCSP strain ANKA genomic DNA was isolated as total DNA from infected red blood cells using Genomic Prep $^{\mathrm{TM}}$ (Amersham) as described by the manufacturer's instructions. Primers PbCSP.1 (AACGTCTCAC ATGCAAAATA AAATCATCCA AGCCCAAAGG AAC) and PbCSP.2 (CGTCTCAAGC TATTAAAGCT TAAGAATTCC GCTTACAATA TTAAATATAC TTGAAC) were used to amplify the PbCSP gene fragment lacking the parts encoding the signal sequence and GPI anchor. The PCR fragment was cloned into vector pCR4TopoBlunt (Invitrogen, Breda, The Netherlands), resulting in plasmid pCR4-PbCSP. The PbCSP specific parts in this plasmid were sequenced (Figure 1). Plasmid pCR4$\mathrm{PbCSP}$ was used as a template for subsequent cloning in the Protan - and His-tag fusion plasmids. All cloning steps that involved PCR were checked by nucleotide sequence analyses (BaseClear, Leiden, The Netherlands).

Plasmid pPA77 (CSP[Tlong]-Protan) encodes the Cterminal part of PbCSP without GPI anchor, but includes $\mathrm{CD}^{+}$and $\mathrm{CD}^{+}$epitopes, coupled to Protan (Figure 2A). The DNA encoding the CSP-Tlong domain was constructed by ligating a NcoI- and EcoRI-cleaved PCR-amplified fragment of $P$. berghei CSP1 into the corresponding sites of plasmid pPA3. The CSP-specific fragment was amplified with the primers CSP-ctl.fw1 (CAAACTCCAT GGGAAATGAC GATTCTTATA TCCC) and CSP-ctl.rev1 (CCTGAGCATG CTCGAAT TCG GCTTACAATA TTAAATATAC TTGAAC) with plasmid pCR4-PbCSP as template. The resulting plasmid pPA77 was used for electroporation of L. lactis PA1001.

Plasmid pPA91 (CSP[Tlong]-His) encodes the same $\mathrm{PbCSP}$ fragment as in plasmid pPA77, coupled to a Histag and a thioredoxin domain (Figure 2A). The DNA encoding the CSP domain was cut from plasmid pPA77 with NcoI and EcoRI and ligated in the corresponding sites of plasmid pET32C. For intracellular production of protein via IPTG induction, plasmid pPA91 was transferred to E. coli strain BL21(DE3).

Plasmid pPA171 (CSP[2xB]-Protan) specifies a fusion between selected B-cell epitopes (32 amino acids) of the $P$. berghei CSP protein ([PPPPNPND $]_{2 x^{-}}$[NANDPAPP] $2 \mathrm{x}$ ) and Protan (Figure 2A). The DNA encoding the Bcell domain was produced by annealing four primers based on L. lactis codon usage. A PCR without template was performed with primers 273 (CGGTCTCACA TGGATATCGG AATTCCTCCA CCTCCAAATC CT AATGATCC ACCTC), 274 (GATCATTAGC ATTAT CATTA GGATTAGgTG GAgGTGGATC ATTAG GATTT), 275 (TAATGATAAT GCTAATGATC CAGCTCCACC TAACGCAAAT GACCCTGCTC) and 
Table 1 Bacterial strains and plasmids used in this study

\begin{tabular}{|c|c|c|}
\hline Strain or Plasmid & Relevant phenotype(s) or genotype(s) ${ }^{a}$ & $\begin{array}{l}\text { Source/ } \\
\text { reference }\end{array}$ \\
\hline PCR4-PbCSP & $\mathrm{Ap}^{r} \mathrm{Km}^{r}$, derivative of pCR4Blunt-TOPO (Invitrogen) containing the Plasmodium berghei CSP gene (Figure 1) & This study \\
\hline pPA3 & $\begin{array}{l}\mathrm{Cm}^{r} \text {, pNZ8048 derivative containing c-myc, the acmA Protan (nucleotides } 835 \text { to 1492) under control of } \\
\text { PnisA, and usp45 ss (PA3) }\end{array}$ & [15] \\
\hline pPA77 & pPA3 derivative producing CSP[Tlong]-Protan & This study \\
\hline pPA91 & $\mathrm{Ap}^{r}$, pET32C (Novagen) derivative producing CSP[Tlong]-His & This study \\
\hline pPA171 & pPA3 derivative producing CSP[2xB]-Protan & This study \\
\hline pPA177 & PPA3 derivative producing CSP[Tshort]-Protan & This study \\
\hline pPA180 & Mucosis laboratory collection, used for subcloning & This study \\
\hline pPA182 & Mucosis laboratory collection, used for subcloning & This study \\
\hline pPA193 & $\mathrm{Ap}^{r}, \mathrm{pET} 32 \mathrm{C}$ (Novagen) derivative producing CSP[2xB]-His & This study \\
\hline pPA197 & pPA177 derivative producing CSP[2xB-Tshort]-Protan & This study \\
\hline pPA198 & pPA177 derivative producing CSP[4xB-Tshort]-Protan & This study \\
\hline $\begin{array}{l}\text { Lactococcus lactis } \\
\text { PA1001 }\end{array}$ & Derivative of NZ9000 lacking acmA and $h t r A$, allows nisin-inducible expression & [15] \\
\hline $\begin{array}{l}\text { Escherichia coli BL21 } \\
\text { (DE3) }\end{array}$ & Allows IPTG-inducible expression & Novagen \\
\hline
\end{tabular}

a) $P_{\text {nisA, }}$ nisin-inducible promoter; usp $45_{s s,}$ signal sequence of usp 45

276 (CGGTCTCTAA TTCCTGGAGG AGCAGGGTCA TTTGCGTTA). A second PCR with only the flanking primers 273 and 276 was performed on the product of the first PCR. The resulting 134 bp product was ligated in the $\mathrm{pCR}^{\circledR} 4$ Blunt-TOPO vector and sequenced. An Eco31I cleaved insert from this plasmid, possessing NcoI and EcoRI overlapping ends, was then transferred into the corresponding sites of vector pPA3. The resulting plasmid pPA171 was used for electroporation of $L$. lactis PA1001.

Plasmid pPA177 (CSP[Tshort]-Protan) specifies a fusion between the $\mathrm{CD}^{+}$and $\mathrm{CD} 4^{+} \mathrm{T}$-cell epitopes of the P. berghei CSP protein and Protan. Compared to the CSP[Tlong]-Protan construct, the CSP[Tshort]-Protan construct lacks the amino acids $\mathrm{C}$-terminal of the predicted $\mathrm{CD}^{+}{ }^{+} \mathrm{T}$-cell epitope (Figure 2A). The DNA encoding the CSP[Tshort] domain was constructed by a PCR without template with four partly overlapping primers 240 (CGGTCTCACA TGGATATCGG AATTCAAAAT GATGATTC), 241 (GGAATTCAAA ATGATGATTC ATATATTCCA TCTGCTGAAA AAATTTTAGA ATTTG), 242 (CCATTCTTCT GTAATACTAT CACGAATTTG TTTAACAAAT TCTAAAATTT TTTCAG) and 243 (CGGTCTCTAA TTTGTGACCA TTCTTCTGTA ATACTATCAC), representing the desired CSP[Tshort] sequence with $L$. lactis optimized codon usage. The product was cloned in the $\mathrm{PCR}^{\circledR} 4$ Blunt-TOPO vector. An Eco31I-cleaved fragment of the resulting vector containing the insert, resulting in $N c o$ I and EcoRI overhanging ends, was ligated into the corresponding sites of plasmid pPA3, thereby replacing the $m y c$-epitope present in pPA3. The resulting plasmid pPA171 was used for electroporation of L. lactis PA1001.
Plasmid pPA193 (CSP[2xB]-His) specifies a fusion between selected B-cell epitopes as in plasmid pPA171, coupled to a His-tag and a thioredoxin domain. The Eco31Icleaved fragment that was used in the construction of pPA177 was ligated in plasmid pPA180, resulting in plasmid pPA182, now containing DNA encoding the B-cell epitope with a C-terminal His-tag. A NcoI and Hind III cleaved fragment of pPA182 was ligated in the corresponding sites of plasmid pET32C, resulting in plasmid pPA193. For intracellular production of protein via IPTG induction, plasmid pPA193 was transferred to E. coli strain BL21(DE3).

Plasmid pPA197 (CSP[2xB-Tshort]-Protan) specifies a fusion between selected B-cell epitopes as in plasmid pPA171, the CSP Tshort epitope (CTL and Th) and Protan, and was constructed by ligating an EcoRIcleaved fragment of pPA171, containing the B-cell epitope, into the EcoRI site of pPA177 in front of the Tshort - Protan fusion. The ligation mix was used for electroporation of $L$. lactis PA1001.

Plasmid pPA198 (CSP[4xB-Tshort]-Protan) specifies a fusion between two selected B-cell epitopes as in plasmid pPA171, the CSP Tshort epitope (CTL and Th) and Protan, and was constructed by ligating two sequential EcoRIcleaved fragments of pPA171, containing the $2 \times \mathrm{B}$ cell epitope, into the EcoRI sites of pPA177. The resulting plasmid pPA198 was used for electroporation of L. lactis PA1001.

\section{Preparation of BLP-PbCSP formulations}

CSP $[2 \mathrm{xB}]-$ His and CSP[Tlong]-His were produced by E. coli using IPTG induction and purified by His-tag isolation for coating of ELISA plates. Purified CSP[Tlong]His was also used for immunizations after addition of incomplete Freund's adjuvant (IF A). 


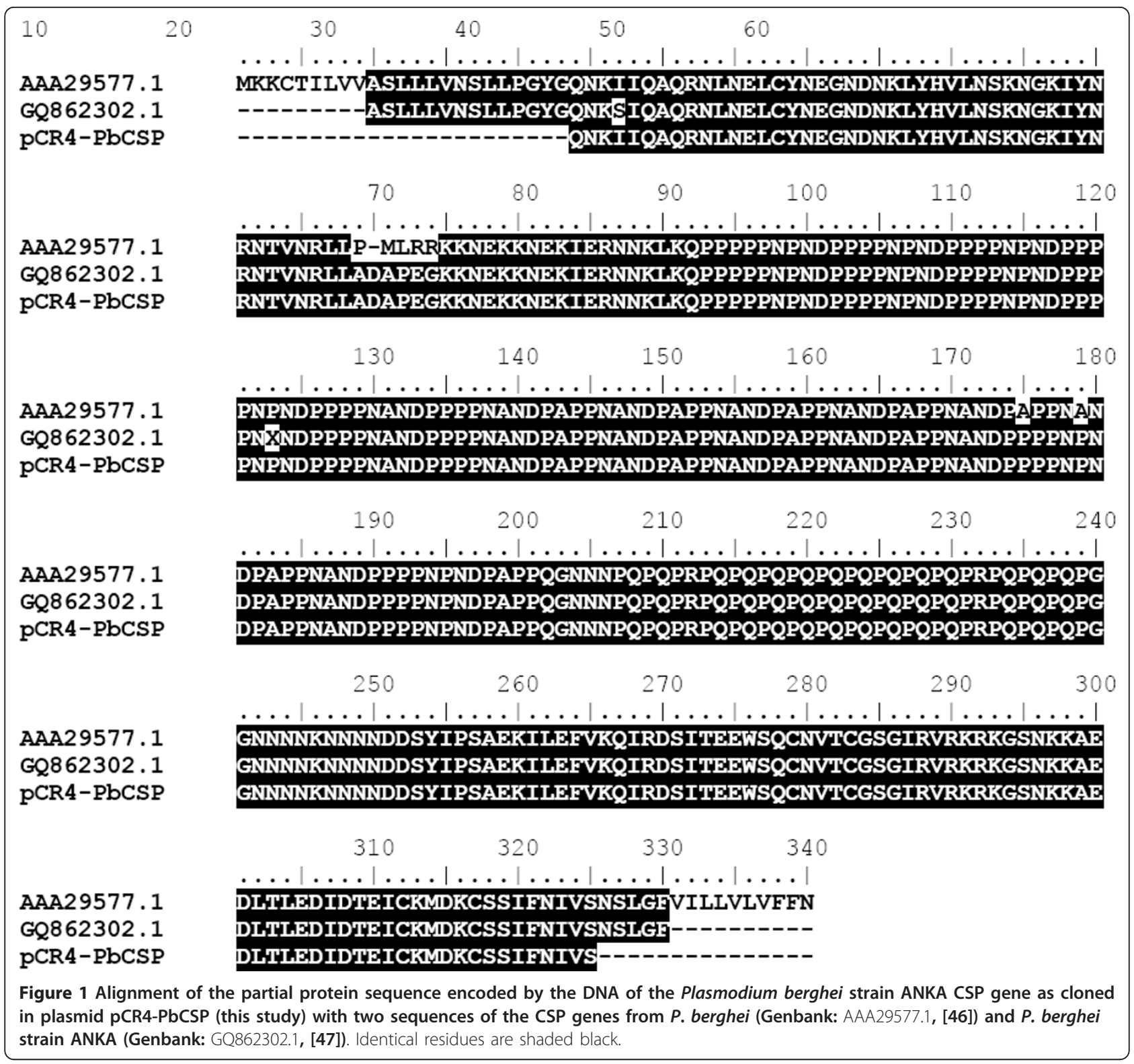

The plasmids pPA171, pPA77 and pPA177 were used to express and secrete the recombinant fusion proteins CSP[2XB]-Protan, CSP[Tlong]-Protan and CSP[Tshort]Protan, respectively (see Figure 2A). BLP-PbCSP were prepared as described elsewhere [16]. Briefly, BLPs were obtained by boiling freshly grown L. lactis NZ9000 in 0.6 $\mathrm{M}$ trichloroacetic acid ( $\mathrm{pH}=1)$ for $30 \mathrm{~min}$, followed by extensive washing with phosphate buffered saline (PBS). Production of the antigen-Protan fusions was induced by addition of nisin to cultures of the appropriate plasmid carrying L. lactis PA1001 strains. Culture supernatants containing the Protan-fusion proteins were 10 times concentrated by ultrafiltration using a VivaFlow system (VivaFlow200, 10,000 Da cut-off, Vivascience, Hannover,
Germany). Binding of antigens was achieved by mixing the concentrates with BLPs under gentle agitation for 30 min at room temperature, followed by extensive washing with PBS.

BLP-PbCSP1 was produced as follows: concentrated supernatant of a CSP[Tlong]-Protan producing L. lactis culture was bound to BLPs on a blood suspension mixer for $30 \mathrm{~min}$ at room temperature. After washing with PBS, CSP $[2 x B]-$ Protan was bound to the BLP-CSP [Tlong]-Protan using the same method. Next, the pellet was washed and re-suspended in PBS, resulting in a $\mathrm{BLP}-\mathrm{PbCSP}$ containing both antigens on a single particle. BLP-PbCSP 1 contained approximately $5 \mu \mathrm{g}$ of CSP [Tlong]-Protan and $20 \mu \mathrm{g}$ CSP[2xB]-Protan per dose. 


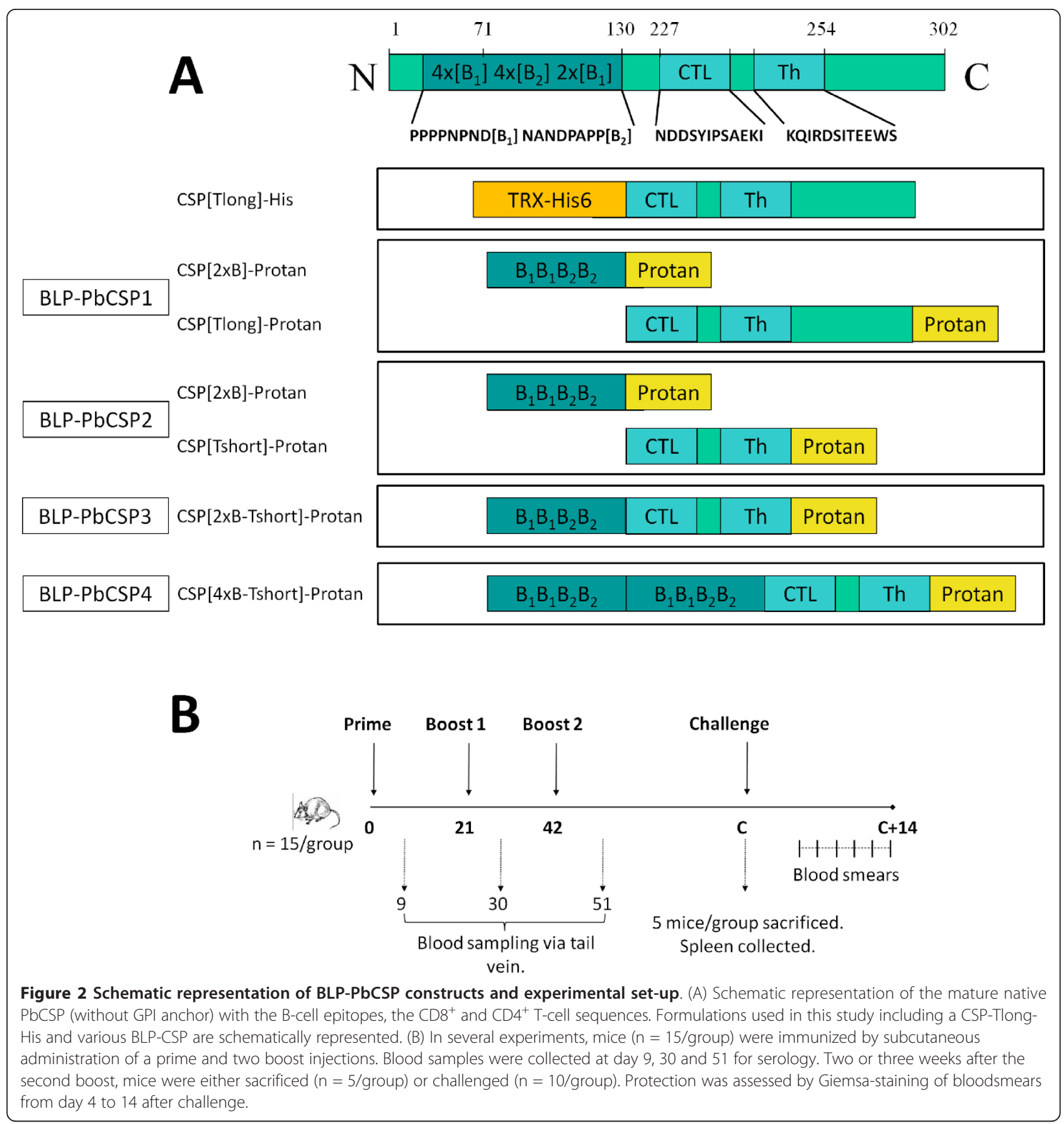

The same approach was used for BLP-PbCSP2, which was produced by first binding the CSP[Tshort]-Protan to the BLP followed by washing and binding of the CSP [2xB]-Protan antigen. BLP-PbCSP2 contained $20 \mu \mathrm{g}$ of CSP [Tshort]-Protan and $20 \mu \mathrm{g}$ CSP[2xB]-Protan per dose. BLP-PbCSP3 and BLP-PbCSP4 contained approximately $45 \mu \mathrm{g}$ of CSP[2xB-Tshort]-Protan per dose. The amount of bound antigen-Protan was estimated using Coomassie brilliant blue stained gels and compared to
BSA protein standards. BLP-PbCSP inocula each contained $2.5 \times 10^{9}$ BLPs in $100 \mu$ l PBS. To formulate the control for BLP-PbCSP1, $10 \mu \mathrm{g}$ CSP[Tlong]-His was emulsified in IFA (Difco Laboratories, Michigan, U.S.A) in final volume of $100 \mu \mathrm{l}$.

\section{Immunization, sample collection and challenge}

All animal experiments were performed with approval of the Animal Experimentation Committee of the 
University of Nijmegen, The Netherlands (DEC2002-89 and DEC2005-70). Female BALB/c mice (six week old) were purchased from Charles River (Germany) and received water and food ad libitum. Mice $(n=15)$ were immunized subcutaneously by injection of $100 \mu \mathrm{l}$ of CSP formulation or PBS, divided into both flanks. Complete immunization consisted of a prime and two boosts injections given at three-week intervals. Two weeks after the last administration, blood samples were collected from the retro-orbital plexus and supplemented with heparin. After centrifugation, plasma was stored at $-20^{\circ}$ $\mathrm{C}$ until use. Immunized mice were either challenged by bites of infected mosquitoes $(n=10)$ or sacrificed for IFN- $\gamma$ ELISPOT assay $(n=5)$ as described below. Challenge of immunized and naive mice was performed by bites of five to eight infected $P$. berghei mosquitoes two to three weeks after the second boost injection. Parasitaemia was determined every other day from day 4 to day 14 by Giemsa-staining of blood smears. Mice that developed parasitaemia were sacrificed on day 12 for ethical reasons. Mice with negative blood smears on day 14 after challenge were considered fully protected. An overview of the experiment is presented in Figure 2B.

\section{Measurement of IFN- $\gamma$ production}

Two weeks after the last immunization, spleens of nonchallenged mice were collected in culture medium (DMEM high glucose, containing Glutamax and supplemented with 10\% FCS and Penicillin/Streptavidin). Spleen cell suspensions were prepared by mechanical dispersion and processed through a $70 \mu \mathrm{m}$ Nylon cell strainer (BD Falcon). Red blood cells were lysed by incubation with ACK buffer $\left(\mathrm{NH}_{4} \mathrm{Cl}\right.$ 0.83\%, $\mathrm{KHCO}_{3} 1 \mathrm{mM}$, EDTA $0.1 \mathrm{mM}$, $\mathrm{pH}=7.4$ ) for $5 \mathrm{~min}$. IFN- $\gamma$ production was measured using the mouse IFN- $\gamma$ ELISPOT kit from BD Biosciences (Erembodegem, Belgium), according to the manufacturer's instruction. Splenocytes were plated at a density of $4 \times 10^{5}$ or $10^{6}$ cells per well and stimulated with the CSP peptide sequence of the CD4+ eptitope KQIRDSITEEWS or the $\mathrm{CD}^{+}$epitope SYIPSAEKI (synthesized by Sigma Genosys). Stimulation with $4 \mu \mathrm{g} / \mathrm{ml}$ PHA (Sigma-Aldrich) served as positive control for the assay. The CSP-Tlong-His formulation (Figure 2A), containing CD4+ and CD8+ T-cell epitopes previously shown to induce IFN- $\gamma$ responses [26-28], served as a positive control. Plates were incubated for 16 hr at $37^{\circ} \mathrm{C}-5 \% \mathrm{CO}_{2}$ prior to IFN- $\gamma$ staining. Spots were counted using the A. EL. VIS (Automated ELISA Spot Assay Video Analysis Systems), Eli. Scan and Eli. Analyse software (Sanquin, Amsterdam, the Netherlands). In all experiments, polyclonal stimulation with PHA showed in all immunized and naïve mice equally high IFN- $\gamma$ response compared to unstimulated conditions $(\mathrm{p}<0.05)$.

\section{Measurement of anti-CSP antibodies}

Specific anti-CSP IgG concentrations were determined by enzyme-linked immuno sorbent assay (ELISA). Briefly, high-binding capacity microtitre plates (Greiner, Alphen aan de Rijn, the Netherlands) were coated with CSP $[2 \mathrm{xB}]-\mathrm{His}-(0.2 \mu \mathrm{g} /$ well $)$ in $0.05 \mathrm{M}$ carbonate buffer $(\mathrm{pH}$ $=9.6$ ) overnight at $4^{\circ} \mathrm{C}$. The plates were washed with PBS - 0.02\% Tween $20(\mathrm{pH}=7.4)$, then incubated for $1 \mathrm{hr}$ with $1 \%$ BSA in PBS/Tween. Diluted sera were added to the plates in three-fold dilutions and incubated for $2 \mathrm{hr}$ at room temperature. After washing, the alkaline phosphatase secondary antibody directed to mouse IgG-Fc (Sigma-Aldrich, Zwijndrecht, The Netherlands) was incubated for $1.5 \mathrm{hr}$ at a dilution 1:5,000. Colorimetric reaction was obtained by addition of p-nitrophenyl phosphate substrate (Sigma-Aldrich) diluted in $0.05 \mathrm{M}$ carbonate buffer $(\mathrm{pH}=9.6)$ supplemented with $1 \mu \mathrm{M} \mathrm{MgCl} 2$. The enzymatic reaction was stopped with $\mathrm{NaOH}$ and read at $405 \mathrm{~nm}$. The CSP specific IgG concentrations were calculated by comparisons with a calibration curve obtained with purified mouse IgG (Sigma-Aldrich).

\section{Statistical analysis}

Comparisons between groups were performed by oneway ANOVA (Kruskas-Wallis test) or by a Mann-Whitney $U$ test using PRISM software version 5.0 (Graphpad, San Diego, CA). $\mathrm{p}<0.05$ was considered statistically significant.

\section{Results}

\section{BLP-PbCSP1 induces parasite-specific antibodies but no} IFN- $\gamma$ response

BLP-PbCSP1 was produced by expression of both CSP $\mathrm{B}$ - and T-cell epitopes in two different Protan fusion products (Figure 2A). Following subcutaneous immunization, B-cell-epitope specific IgG levels were determined by ELISA nine days after prime (day 9) and each boost injection (day 30 and 51). The prime injection induced low levels of B-cell-epitope specific IgG levels that significantly increased after the first boost injection $(\mathrm{p}=0.008)$ and remained at similar levels upon the second boost (Figure 3A). Prior to challenge, IFN- $\gamma$ response was assessed by ELISPOT in five of the 15 BLP-PbCSP1 immunized mice. However, no IFN- $\gamma$ response could be observed after stimulation with CSP epitopes (Figure 3B).

\section{Partial protection by BLP-PbCSP1}

Next, protection in 10 BLP-PbCSP1 immunized mice was assessed by performing a mosquito challenge three weeks after the second boost. At day 14 post-challenge, BLP-PbCSP1 showed complete protection in 40\% (4/10) 


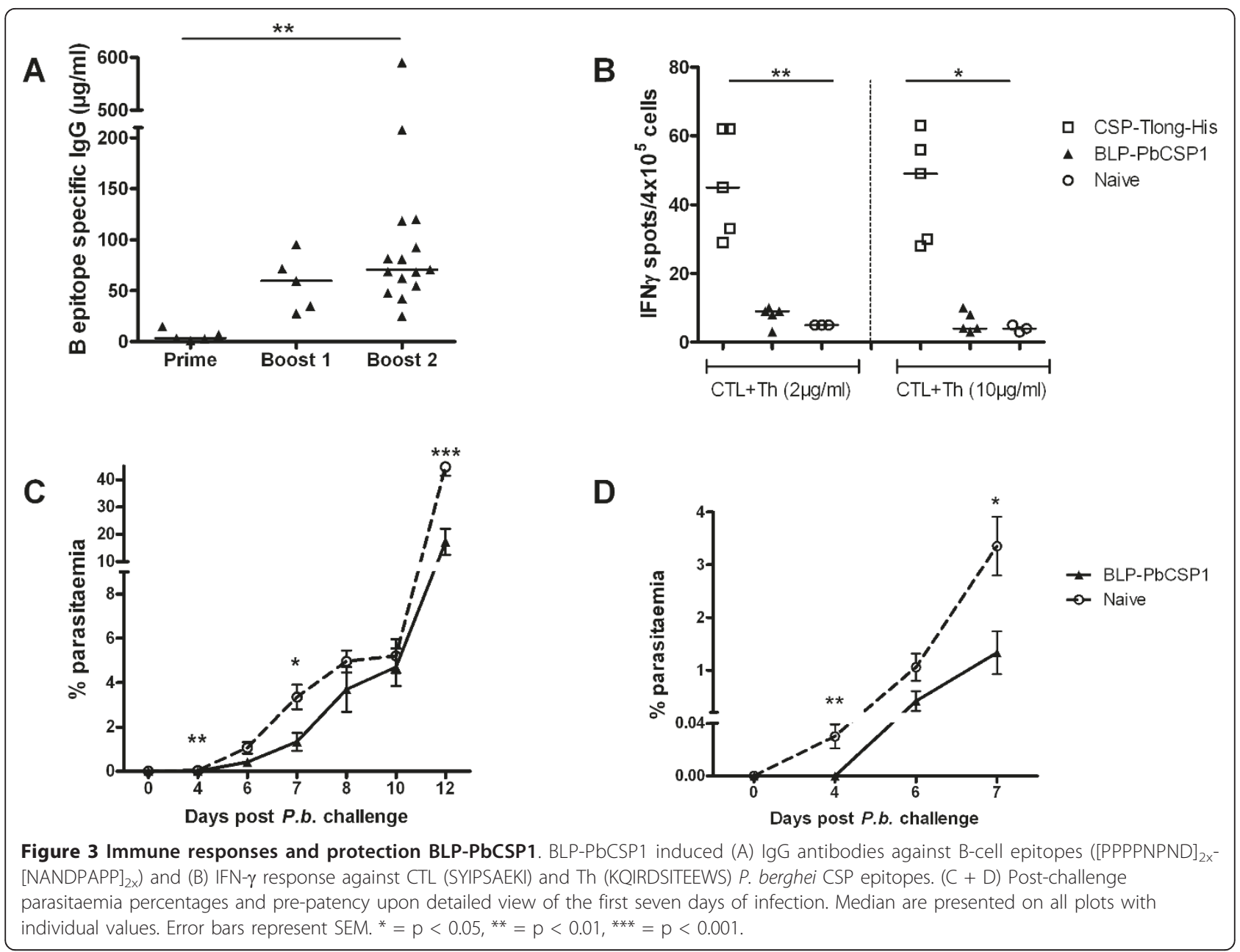

of the mice (Table 2) and the development of bloodstage parasites in immunized unprotected mice did not differ from naive mice (Figure 3C). However, the prepatent period of unprotected mice was significantly extended for two days compared to naive mice suggestive for partial immunity (Figure 3D).

Table 2 Protection by BLP-PbCSP1, 2 and 4 upon Plasmodium berghei sporozoite challenge

\begin{tabular}{llll}
\hline & & No. protected/No. challenged & \% protection \\
\hline Exp 1 & BLP-PbCSP1 & $4 / 10$ & $40 \%$ \\
& Naive & $0 / 10$ & $0 \%$ \\
\hline \multirow{2}{*}{ Exp 2 } & BLP-PbCSP1 & $3 / 10$ & $30 \%$ \\
& BLP-PbCSP2 & $7 / 10$ & $70 \%$ \\
& Naive & $0 / 10$ & $0 \%$ \\
\hline \multirow{4}{*}{ Exp 3 } & BLP-PbCSP2 & $6 / 10$ & $60 \%$ \\
& BLP-PbCSP4 & $9 / 9$ & $100 \%$ \\
& Naive & $1 / 10$ & $10 \%$ \\
\hline
\end{tabular}

Improved immune responses and protection by optimized BLP-PbCSP2

To further improve BLP-PbCSP, codons were optimized for higher production in L. lactis and the length of the non-immunogenic sequence of the T-cell epitope was shortened. Optimization resulted in a new fusion protein BLP-PbCSP2 with CSP[Tshort]-Protan bound to $\mathrm{BLP}$ in equal amounts as the CSP[2xB]-Protan (Figure $2 \mathrm{~A}$ ). Following a prime and two boost injections (Figure 2B), BLP-PbCSP2 immunized mice developed slightly higher concentrations $(\mathrm{p}=0.05)$ of $\mathrm{B}$-cell epitope specific IgG levels compared to BLP-PbCSP1 (Figure 4A). Unlike BLP-PbCSP1 however, ELISPOT IFN- $\gamma$ levels were high in response to both CTL and Th peptides (Figure 4B). Thus optimization of the BLP-PbCSP1 resulted in BLP-PbCSP2 with slightly higher humoral and enhanced cellular responses. Challenge of BLPPbCSP1 and BLP-PbCSP2 immunized mice was performed two weeks after the second boost. Complete protection was observed by day 14 post-challenge in $30 \%(3 / 10)$ of BLP-PbCSP1 and in $70 \%(7 / 10)$ of BLP- 


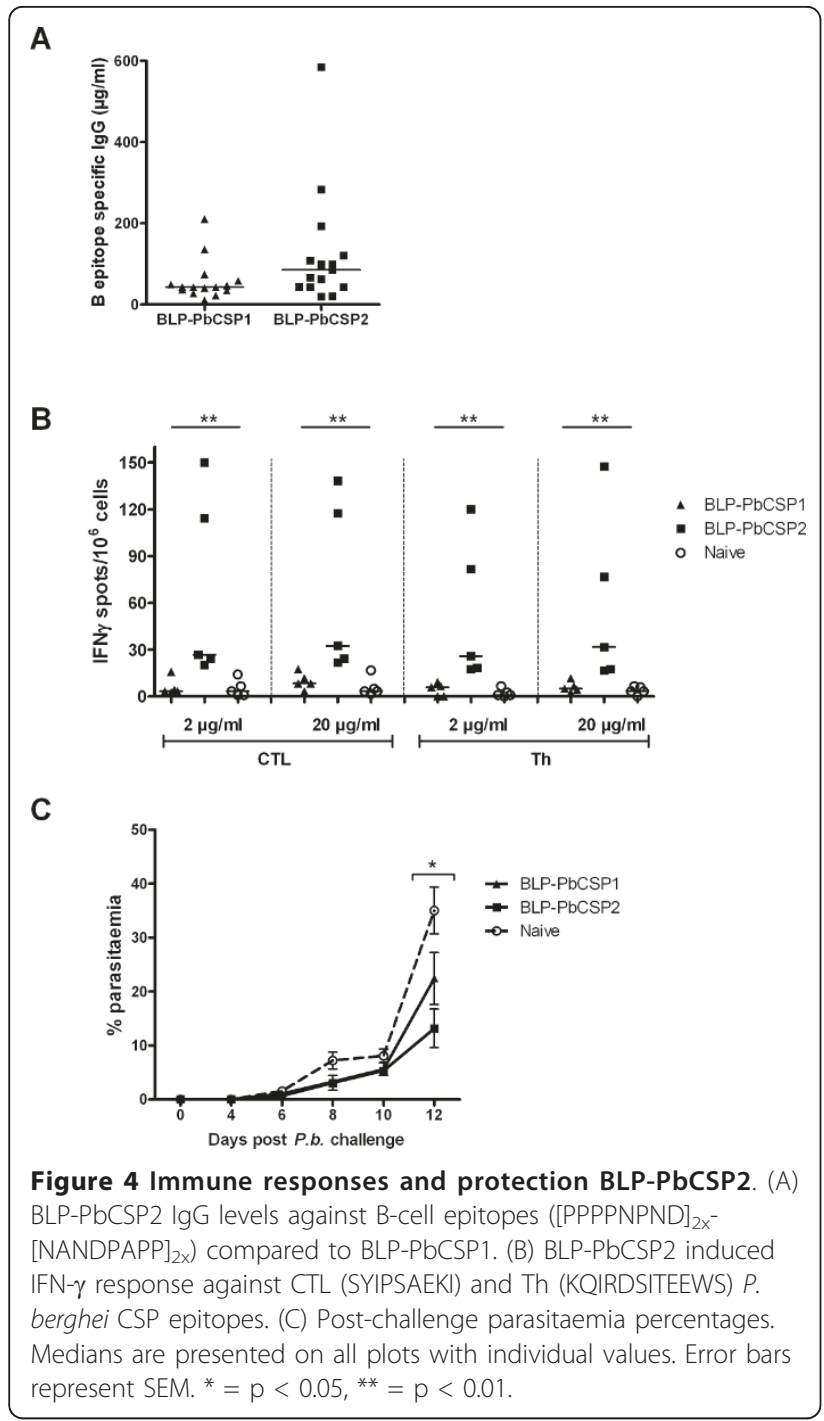

PbCSP2 immunized mice (Table 2). Parasitaemia of the BLP-PbCSP2 immunized mice was significantly lower on day 12 in unprotected immunized mice $(\mathrm{p}=0.02)$ compared to naive mice (Figure $4 \mathrm{C}$ ).

\section{Stronger immune response and $100 \%$ protection by BLP- PbCSP4}

Finally, to further improveme humoral responses induced by BLP-PbCSP, B-cell and T-cell epitopes were fused to formulate BLP-PbCSP3 and B-cell epitopes were duplicated in BLP-PbCSP4 (Figure 2A). Anti-B-cell epitope IgG responses generated by BLP-PbCSP4 were marginally higher compared to BLP-PbCSP3 $(145 \mu \mathrm{g} / \mathrm{ml}$ and $104 \mu \mathrm{g} / \mathrm{ml}$ respectively, data not shown). Immunization with BLP-PbCSP4 induced significantly higher IgG antibody levels against B-cell epitopes as compared to BLP-PbCSP2 immunized and naïve mice $(\mathrm{p}<0.0001)$, (Figure 5A). Furthermore, significantly higher CTL- and

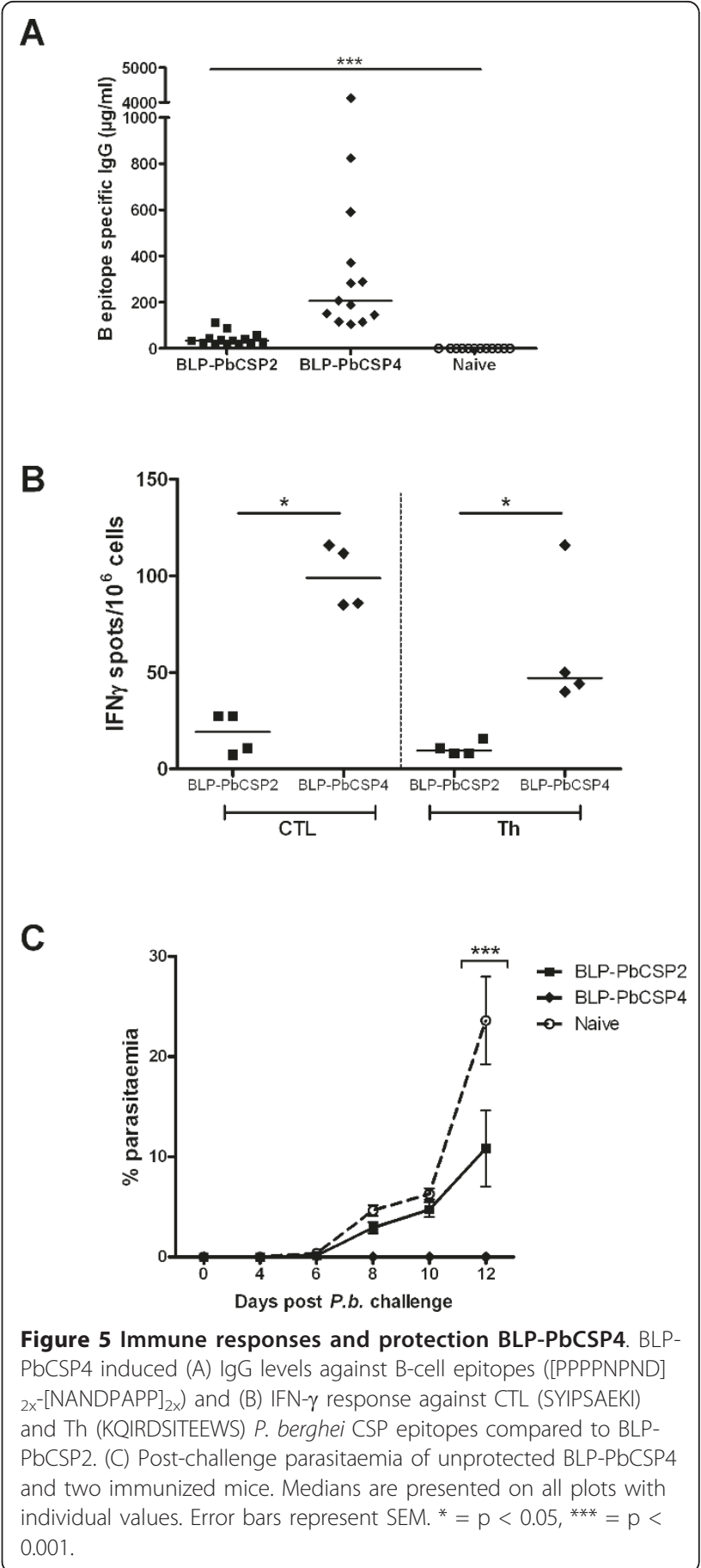

Th-specific IFN- $\gamma$ responses were observed by splenocytes from BLP-PbCSP4 ( $\mathrm{p}=0.03$ ) compared to BLP$\mathrm{PbCSP} 2$ immunized mice (Figure 5B). Following challenge (two weeks after the second boost), complete protection was observed in $60 \%(6 / 10)$ of BLP-PbCSP2 and in $100 \%$ (9/9) of BLP-PbCSP4 immunized mice (Table $2)$. In line with the previous experiment, unprotected mice immunized with BLP-PbCSP2 showed a significant 
lower parasitaemia $(\mathrm{p}=0.03)$ at day 12 . All mice immunized with BLP-PbCSP4 developed sterile immunity (Figure 5C). Thus, optimization of the BLP-PbCSP formulations resulted in high $\mathrm{T}$ - and $\mathrm{B}$-cell responses that provided complete protection in all $P$. berghei immunized mice.

\section{Discussion}

The present study reports $100 \%$ protection against $P$. berghei malaria induced by subunits of PbCSP using bacterium-like particles (BLPs) as self-adjuvanting delivery system. Following subcutaneous immunization, BLPPbCSP formulations are able to trigger both specific IgG antibodies and IFN $-\gamma$ response to $\mathrm{CD} 4+$ and $\mathrm{CD} 8+\mathrm{T}$ cell epitopes. Both humoral and cellular responses have been shown to be relevant for protection against malaria parasites in different murine models [29-32]. Identification and use of specific T- and B-cell epitopes has been valuable for understanding the protective immune response induced by CSP-based constructs [28,32-34]. Immunization with virally vectored $P$. berghei CSP shows low immune responses and protection levels following prime-boost regimen with a single carrier [10-13]. However, immune responses and protection rates are high when different viral vectors for $P$. berghei or Plasmodium yoelii CSP are used [10-13,35]. Seemingly, the benefits of VLP-based carrier combinations for induction of high protective efficacy apply to several Plasmodium species. Similarly, prime-boost P. berghei CSP immunizations with Salmonella or Bordetella-based carriers show lower protective efficacy compared to the combination of both carriers [36]. The current data show that homologous prime-boosting with L. lactis $\mathrm{BLP}-\mathrm{PbCSP}$ is sufficient to induce sterile protection, illustrating the potency of this platform for effec!tive delivery of malaria epitopes.

The several epitope modifications explored to improve immune responses of BLP-PbCSP constructs included codon optimization, reduction of the non-immunogenic part in the T-cell epitopes as well as fusion of $\mathrm{B}$ - and $\mathrm{T}$ cell epitopes. As previously shown, codon optimization can improve adequate production of malaria antigens [37]. The improved cellular responses reported here cannot be clearly explained by either codon optimization or modification of $\mathrm{T}$-cell epitopes. As for humoral responses, $\mathrm{CD} 4+$ helper $\mathrm{T}$ cells contribute to $\mathrm{B}$-cell responses and even more so are prerequisite to IgG production. Tam et al. reported highest antibodies titres and highest protection levels by tandemly connected $\mathrm{T}$ and B-cell epitopes of PbCSP [38]. Accordingly, improved $\mathrm{T}$ helper responses may indirectly account for the somewhat increased IgG responses to BLP-PbCSP2. As presented in Figure 3, immunization with BLPPbCSP1 induces high levels of B-cell epitope specific
IgG but no CTL/Th specific IFN- $\gamma$ response, resulting in low protection level and significant delayed parasitemia. While immunization with BLP-PbCSP2 merely induces slightly higher levels of B-cell epitope specific IgG, the significantly higher CTL/Th specific IFN- $\gamma$ response associates with higher protection level and further delayed parasitaemia. Eventually, BLP-PbCSP4 induces the highest levels of humoral and cellular responses but also complete protection. Clearly, induction of specific antibodies is sufficient to induce a minimal protective efficacy. For complete protection however, both potent humoral and cellular responses are apparently required. Whether contribution, if any, of the Th response to humoral response leads to qualitatively superior specific IgG antibodies is an interesting consideration to explore in future studies.

Moreover, CSP contains several epitopes that have been shown to induce B-cell $[32,39,40]$ as well as CD4+ and CD8+ T-cell $[30,41,42]$ protective immune responses. The present study clearly further illustrates that modifications in both T- and B-cell CSP epitopes can have major effects on immune responses and protective efficacy as shown before [38]. In addition, there is increasing evidence of the protective role of non-CSP pre-erythrocytic malaria antigens [43-45]. Immunization studies with some recently identified candidates could be performed using the L. lactis BLP-carrier whose immuno-modulating properties that induce local and systemic immune responses $[17,19,21]$, are an asset for efficient protection studies with potentially multiple antigen peptides. Recent launch of a phase I clinical study with FluGEM ${ }^{\mathrm{TM}}$, an influenza vaccine with $L$. lactis BLP as delivery platform, paved the way towards vaccines delivery by this non-living and non-genetically modified carrier. Eventually, BLPs derived from the food-grade bacterium $L$. lactis could also be evaluated as a delivery system for a malaria vaccine.

In conclusion, immunizations with BLP-PbCSP formulation containing $\mathrm{B}$ - and $\mathrm{T}$-cell epitopes induce strong humoral and cellular responses that result in complete protection in mice. L. lactis BLPs are potentially a delivery system for the development of a safe and affordable malaria vaccine with high protective efficacy.

\section{Abbreviations}

BLP: Bacterium-like particle; (Pb)CSP: (Plasmodium berghei) circumsporozoite protein.

\section{Acknowledgements}

The authors are grateful to Prof. Ranjan Ramasamy and Prof. Jan Kok for cloning of the PbCSP gene and making available the gene sequence, work that was part of a WOTRO project (financed by the Netherlands Organisation for Scientific Research [NWO]). K. Nganou was supported by the NWO Mozaiek grant No. 017.005.011. The authors thank Jolanda Neef, Heidi Metselaar, Louwe de Vries and Liselotte Wolters for technical assistance. We would like to thank as well Jolanda Klaassen, Laura Pelser-Posthumus, Astrid 
Pouwelsen and Jacqueline Kuhnen for assistance with P. berghei infections and mosquito dissections. The authors are also thankful to Marijke Haas for stimulating discussions and George Robillard for supporting this work.

\section{Author details}

'Department of Medical Microbiology, Radboud University Nijmegen Medical Centre, P. O. Box 9101, 6500 HB Nijmegen, The Netherlands. ${ }^{2}$ Mucosis BV, Groningen, The Netherlands. ${ }^{3} \mathrm{BiOMaDe}$ Technology Foundation, Groningen, The Netherlands.

\section{Authors' contributions}

$\mathrm{KN}$ performed data analysis and drafted the manuscript. MvR, $\mathrm{KL}, \mathrm{CH}$ and RS helped to draft the manuscript. GvG carried out mosquito challenge. MvR and SA carried out the study conceived and coordinated by $\mathrm{KL}, \mathrm{CH}$ and $\mathrm{RS}$. All authors read and approved the final manuscript.

\section{Competing interests}

The authors declare that they have no competing interests.

Received: 7 November 2011 Accepted: 20 February 2012 Published: 20 February 2012

\section{References}

1. WHO: World Malaria Report 2010 World Health Organization, Geneva; 2010.

2. Hill AV, Reyes-Sandoval A, O'Hara G, Ewer K, Lawrie A, Goodman A, Nicosia A, Folgori A, Colloca S, Cortese R, Gilbert SC, Draper SJ: Prime-boost vectored malaria vaccines: progress and prospects. Hum Vaccin 2010, 6:78-83.

3. Kanoi BN, Egwang TG: New concepts in vaccine development in malaria. Curr Opin Infect Dis 2007, 20:311-316.

4. Limbach KJ, Richie TL: Viral vectors in malaria vaccine development. Parasite Immunol 2009, 31:501-519.

5. Nussenzweig V, Nussenzweig RS: Circumsporozoite proteins of malaria parasites. Cell 1985, 42:401-403.

6. Oliveira GA, Wetzel K, Calvo-Calle JM, Nussenzweig R, Schmidt A, Birkett A Dubovsky F, Tierney E, Gleiter CH, Boehmer G, Luty AJ, Ramharter M, Thornton GB, Kremsner PG, Nardin EH: Safety and enhanced immunogenicity of a hepatitis B core particle Plasmodium falciparu malaria vaccine formulated in adjuvant Montanide ISA 720 in a phase I trial. Infect Immun 2005, 73:3587-3597.

7. Stoute JA, Heppner DG Jr, Mason CJ, Siangla J, Opollo MO, Kester KE, Vigneron L, Voss G, Walter MJ, Tornieporth N, Cohen JD, Ballou WR: Phase 1 safety and immunogenicity trial of malaria vaccine RTS, S/AS02A in adults in a hyperendemic region of western Kenya. Am J Trop Med Hyg 2006, 75:166-170.

8. Sun P, Schwenk R, White K, Stoute JA, Cohen J, Ballou WR, Voss G, Kester KE, Heppner DG, Krzych U: Protective immunity induced with malaria vaccine, RTS, $\mathrm{S}$, is linked to Plasmodium falciparum circumsporozoite protein-specific CD4+ and CD8+ T cells producing IFNgamma. J Immunol 2003, 171:6961-6967.

9. Walther M, Thompson FM, Dunachie S, Keating S, Todryk S, Berthoud T, Andrews L, Andersen RF, Moore A, Gilbert SC, Poulton I, Dubovsky F, Tierney E, Correa S, Huntcooke A, Butcher G, Williams J, Sinden RE, Hill AV: Safety, immunogenicity, and efficacy of prime-boost immunization with recombinant poxvirus FP9 and modified vaccinia virus Ankara encoding the full-length Plasmodium falciparu circumsporozoite protein. Infect Immun 2006, 74:2706-2716.

10. Gilbert SC, Schneider J, Hannan CM, Hu JT, Plebanski M, Sinden R, Hill AV: Enhanced CD8 T cell immunogenicity and protective efficacy in a mouse malaria model using a recombinant adenoviral vaccine in heterologous prime-boost immunisation regimes. Vaccine 2002, 20:1039-1045.

11. Hutchings $C L$, Birkett AJ, Moore AC, Hill AV: Combination of protein and viral vaccines induces potent cellular and humoral immune responses and enhanced protection from murine malaria challenge. Infect Immun 2007, 75:5819-5826.

12. Murata K, Garcia-Sastre A, Tsuji M, Rodrigues M, Rodriguez D, Rodriguez JR, Nussenzweig RS, Palese P, Esteban M, Zavala F: Characterization of in vivo primary and secondary CD8+ $T$ cell responses induced by recombinant influenza and vaccinia viruses. Cell Immunol 1996, 173:96-107.
13. Plebanski M, Gilbert SC, Schneider J, Hannan CM, Layton G, Blanchard T, Becker M, Smith G, Butcher G, Sinden RE, Hill AV: Protection from Plasmodium berghe infection by priming and boosting $\mathrm{T}$ cells to a single class I-restricted epitope with recombinant carriers suitable for human use. Eur J Immunol 1998, 28:4345-4355.

14. Buchbinder SP, Mehrotra DV, Duerr A, Fitzgerald DW, Mogg R, Li D, Gilbert PB, Lama JR, Marmor M, Del Rio C, McElrath MJ, Casimiro DR, Gottesdiener KM, Chodakewitz JA, Corey L: Robertson MN; Step Study Protocol Team: Efficacy assessment of a cell-mediated immunity HIV-1 vaccine (the Step Study): a double-blind, randomised, placebocontrolled, test-of-concept trial. Lancet 2008, 372:1881-1893.

15. Bosma T, Kanninga R, Neef J, Audouy SA, van Roosmalen ML, Steen A, Buist G, Kok J, Kuipers OP, Robillard G, Leenhouts K: Novel surface display system for proteins on non-genetically modified gram-positive bacteria. Appl Environ Microbiol 2006, 72:880-889.

16. van Roosmalen ML, Kanninga R, El KM, Neef J, Audouy S, Bosma T, Kuipers A, Post E, Steen A, Kok J, Buist G, Kuipers OP, Robillard G, Leenhouts K: Mucosal vaccine delivery of antigens tightly bound to an adjuvant particle made from food-grade bacteria. Methods 2006, 38:144-149.

17. Audouy SA, van Roosmalen ML, Neef J, Kanninga R, Post E, van DM, Metselaar H, van SS, Robillard GT, Leenhouts KJ, Hermans PW: Lactococcus lacti GEM particles displaying pneumococcal antigens induce local and systemic immune responses following intranasal immunization. Vaccine 2006, 24:5434-5441.

18. Buist G, Steen A, Kok J, Kuipers OP: LysM, a widely distributed protein motif for binding to (peptido)glycans. Mol Microbiol 2008, 68:838-847.

19. Saluja V, Amorij JP, van Roosmalen ML, Leenhouts K, Huckriede A, Hinrichs WL, Frijlink HW: Intranasal delivery of influenza subunit vaccine formulated with GEM particles as an adjuvant. AAPSJ 2010, 12:109-116.

20. Saluja V, Visser MR, Ter VW, van Roosmalen ML, Leenhouts K, Hinrichs WL, Huckriede A, Frijlink HW: Influenza antigen-sparing by immune stimulation with Gram-positive enhancer matrix (GEM) particles. Vaccine 2010, 28:7963-7969.

21. Ramirez K, Ditamo Y, Rodriguez L, Picking WL, van Roosmalen ML, Leenhouts K, Pasetti MF: Neonatal mucosal immunization with a nonliving, non-genetically modified Lactococcus lacti vaccine carrier induces systemic and local Th1-type immunity and protects against lethal bacterial infection. Mucosal Immunol 2010, 3:159-171.

22. Audouy SA, van SS, van Roosmalen ML, Post E, Kanninga R, Neef J, Estevao S, Nieuwenhuis EE, Adrian PV, Leenhouts K, Hermans PW: Development of lactococcal GEM-based pneumococcal vaccines. Vaccine 2007, 25:2497-2506.

23. Ramasamy R, Yasawardena S, Zomer A, Venema G, Kok J, Leenhouts K: Immunogenicity of a malaria parasite antigen displayed by Lactococcus lactis in oral immunisations. Vaccine 2006, 24:3900-3908.

24. Kuipers OP, Beerthuyzen MM, de Ruyter PG, Luesink EJ, de Vos WM: Autoregulation of nisin biosynthesis in Lactococcus lacti by signal transduction. JBiolChem 1995, 270:27299-27304.

25. Holo H: Nes IF. High-frequency transformation by electroporation of Lactococcus lactis subsp cremoris grown with glycine in osmotically stabilized media Appl Environ Microbiol 1989, 55:3119-3123.

26. Meraldi V, Audran R, Romero JF, Brossard V, Bauer J, Lopez JA, Corradin G: OM-174, a new adjuvant with a potential for human use, induces a protective response when administered with the synthetic C-terminal fragment 242-310 from the circumsporozoite protein of Plasmodium berghe. Vaccine 2003, 21:2485-2491.

27. Meraldi V, Romero JF, Kensil C, Corradin G: A strong CD8+ T cell response is elicited using the synthetic polypeptide from the C-terminus of the circumsporozoite protein of Plasmodium berghe together with the adjuvant QS-21: quantitative and phenotypic comparison with the vaccine model of irradiated sporozoites. Vaccine 2005, 23:2801-2812.

28. Romero P, Maryanski JL, Corradin G, Nussenzweig RS, Nussenzweig V, Zavala F: Cloned cytotoxic T cells recognize an epitope in the circumsporozoite protein and protect against malaria. Nature 1989, 341:323-326

29. Bruna-Romero O, Rocha CD, Tsuji M, Gazzinelli RT: Enhanced protective immunity against malaria by vaccination with a recombinant adenovirus encoding the circumsporozoite protein of Plasmodium lacking the GPIanchoring motif. Vaccine 2004, 22:3575-3584. 
30. Heal KG, Sheikh NA, Hollingdale MR, Morrow WJ, Taylor-Robinson AW: Potentiation by a novel alkaloid glycoside adjuvant of a protective cytotoxic $T$ cell immune response specific for a preerythrocytic malaria vaccine candidate antigen. Vaccine 2001, 19:4153-4161.

31. Romero JF, Ciabattini A, Guillaume P, Frank G, Ruggiero P, Pettini E, Del GG, Medaglini D, Corradin G: Intranasal administration of the synthetic polypeptide from the C-terminus of the circumsporozoite protein of Plasmodium berghe with the modified heat-labile toxin of Escherichia col (LTK63) induces a complete protection against malaria challenge. Vaccine 2009, 27:1266-1271

32. Zavala F, Tam JP, Barr PJ, Romero PJ, Ley V, Nussenzweig RS, Nussenzweig $V$ : Synthetic peptide vaccine confers protection against murine malaria. J Exp Med 1987, 166:1591-1596.

33. Ballou WR, Rothbard J, Wirtz RA, Gordon DM, Williams JS, Gore RW, Schneider I, Hollingdale MR, Beaudoin RL, Maloy WL: Immunogenicity of synthetic peptides from circumsporozoite protein of Plasmodium falciparu. Science 1985, 228:996-999.

34. Romero PJ, Tam JP, Schlesinger D, Clavijo P, Gibson H, Barr PJ, Nussenzweig RS, Nussenzweig $V$, Zavala F: Multiple T helper cell epitopes of the circumsporozoite protein of Plasmodium berghe. Eur J Immunol 1988, 18:1951-1957.

35. Oliveira-Ferreira J, Miyahira Y, Layton GT, Savage N, Esteban M, Rodriguez D, Rodriguez JR, Nussenzweig RS, Zavala F: Immunogenicity of Ty-VLP bearing a CD8(+) T cell epitope of the CS protein of $P$. yoelii: enhanced memory response by boosting with recombinant vaccinia virus Vaccine. 2000, 18:1863-1869.

36. Tartz S, Russmann H, Kamanova J, Sebo P, Sturm A, Heussler V, Fleischer B, Jacobs T: Complete protection against $P$ berghei malaria upon heterologous prime/boost immunization against circumsporozoite protein employing Salmonella type III secretion system and Bordetella adenylate cyclase toxoid Vaccine. 2008, 26:5935-5943.

37. Birkholtz LM, Blatch G, Coetzer TL, Hoppe HC, Human E, Morris EJ, Ngcete Z, Oldfield L, Roth R, Shonhai A, Stephens L, Louw Al: Heterologous expression of plasmodial proteins for structural studies and functional annotation. Malar J 2008, 7:197.

38. Tam JP, Clavijo P, Lu YA, Nussenzweig V, Nussenzweig R, Zavala F: Incorporation of $T$ and $B$ epitopes of the circumsporozoite protein in a chemically defined synthetic vaccine against malaria. J Exp Med 1990, 171:299-306

39. Heppner DG, Gordon DM, Gross M, Wellde B, Leitner W, Krzych U, Schneider I, Wirtz RA, Richards RL, Trofa A, Hall T, Sadoff JC, Boerger P, Alving CR, Sylvester DR, Porter TG, Ballou WR: Safety, immunogenicity, and efficacy of Plasmodium falciparu repeatless circumsporozoite protein vaccine encapsulated in liposomes. J Infect Dis 1996, 174:361-366.

40. Schwenk R, Asher LV, Chalom I, Lanar D, Sun P, White K, Keil D, Kester KE, Stoute J, Heppner DG, Krzych U: Opsonization by antigen-specific antibodies as a mechanism of protective immunity induced by Plasmodium falciparu circumsporozoite protein-based vaccine. Parasite Immunol 2003, 25:17-25.

41. Reece $W H$, Pinder M, Gothard PK, Milligan P, Bojang K, Doherty T, Plebanski M, Akinwunmi P, Everaere S, Watkins KR, Voss G, Tornieporth N, Alloueche A, Greenwood BM, Kester KE, McAdam KP, Cohen J, Hill AV: A CD4(+) T-cell immune response to a conserved epitope in the circumsporozoite protein correlates with protection from natural Plasmodium falciparu infection and disease. Nat Med 2004, 10:406-410.

42. Roggero MA, Meraldi V, Lopez JA, Eberl G, Romero JC, Matile H, Betschart B, Corradin G, Renggli J: The synthetic, oxidized C-terminal fragment of the Plasmodium berghe circumsporozoite protein elicits a high protective response. Eur J Immunol 2000, 30:2679-2685.

43. Grüner AC, Mauduit M, Tewari R, Romero JF, Depinay N, Kayibanda M, Lallemand E, Chavatte JM, Crisanti A, Sinnis P, Mazier D, Corradin G, Snounou G, Rénia L: Sterile protection against malaria is independent of immune responses to the circumsporozoite protein. PLoSOne 2007, 2: e1371.

44. Mauduit M, Tewari R, Depinay N, Kayibanda M, Lallemand E, Chavatte JM, Snounou G, Renia L, Grüner AC: Minimal role for the circumsporozoite protein in the induction of sterile immunity by vaccination with live rodent malaria sporozoites. Infect/mmun 2010, 78:2182-2188.

45. Mishra S, Rai U, Shiratsuchi T, Li X, Vanloubbeeck Y, Cohen J, Nussenzweig RS, Winzeler EA, Tsuji M, Nussenzweig V: Identification of
non-CSP antigens bearing CD8 epitopes in mice immunized with irradiated sporozoites. Vaccine 2011, 29:7335-7342.

doi:10.1186/1475-2875-11-50

Cite this article as: Nganou-Makamdop et al:: Bacterium-like particles as multi-epitope delivery platform for Plasmodium berghei circumsporozoite protein induce complete protection against malaria in mice. Malaria Journal 2012 11:50.

\section{Submit your next manuscript to BioMed Central and take full advantage of:}

- Convenient online submission

- Thorough peer review

- No space constraints or color figure charges

- Immediate publication on acceptance

- Inclusion in PubMed, CAS, Scopus and Google Scholar

- Research which is freely available for redistribution

Submit your manuscript at www.biomedcentral.com/submit
Biomed Central 